\title{
一次視覚野の機能構築と光の役割
}

\author{
佐 藤 宏 道・勝 山 成 美 \\ （大阪大学医学部バイオメディカルセンター神経生理）
}

\section{Functional Organization and Roles of the Primary Visual Cortex}

\author{
Hiromichi Sato, Narumi Katsuyama \\ Department of Neurophysiology, Biomedical Research Center \\ Osaka University, Medical School
}

\begin{abstract}
サルの大脳皮質一次視覚野 $(\mathrm{V} 1)$ の機能と構造の関連を理解する枠組を概説するとともに, V1が視 覚中枢の中でどのように位置付けられるのかを最近の知見を交えて概説した. V1の機能構築を理解す るには, 網膜部位再現, 層分化, ニューロン活動の刺激特異性, 機能円柱などについて知ることが重 要である．また視覚情報の流れとV1の役割を機能面および構造面から理解するのには，視覚刺激の 運動や立体視の情報を運ぶ大細胞系 (magnocellular system) と，形態や色などの情報を運ぶ小細胞 系 (parvocellular system) という V1にいたるまで並列な 2 つの経路の違いを知ることが助けとなる. 両系によってV1に入力された情報は, それぞれの刺激特徴を専門に処理する並列な計算モジュール である機能円柱内で層間の階層的な処理を経た後, 高次視覚野に分配出力される. 視野の一点の情報 を処理している各々のV1ニューロンの活動が，視野全体の再構築のためにどのように統合されてい るかについては不明の点が多いが，光学的計測法など新技術を導入した研究によってこの問題につい て新たな発展が期待される。
\end{abstract}

Functional organization of the primary visual cortex (V1) was reviewed with particular reference to retinotopic representation of visual field, laminar organization, stimulus-specific response properties and functional columns in V1. The parallel information processing system consists of at least two channels, the magnocellular channel, dealing with brightness contrast and motion of visual stimuli, and parvocellular channel, dealing with color and form. These two channels are retinal in origin and meet in V1. Newly differentiated three pathways dealing color, form and motion carry information from V1 to distinct areas in V2. Columnar structures such as ocular dominance column, orientation column and cytochrome oxidase-rich blob are functional modules for processing particular kinds of information coming from a given point in the visual field. Even though it is not clear that how the locally processed information is integrated across the V1, an introduction of newly developed technique, in vivo optical recording of cortical activity, into the study is expected to make a marked progress in understanding of the temporal and spatial integration of functions in V1.

連絡先

（予565）吹田市山田丘 2-2

大阪大学医学部

バイオメディカルセンター神経生理

TEL (06) 879-3661 FAX (06) 879-3669

Key words: the primary visual cortex, retinotopic representation of visual field, laminar organization, stimulus-specific response property, functional column, magnocellular system, parvocellular system

\section{I. 緒言}

大脸皮質一次視覚野（17野あるいはV1）の構 造および機能については 1950年代末から 1960年 代初めの Hubel とWiesel の研究1)-3) 端緒とし て,これまでに膨大な量の研究成果が蓄積され てきた．視覚系における生理学的, 解剖学的実 験は, 用いる視覚刺激とニューロンの活動特性 の関連,さらに形態学的な構造との対応を調べ 
やすいため, V1を舞台として機能構築, 可塑性, 神経伝達物質, 情報処理メカニズムなど様々の 問題が検討されてきた。 その成果は単に視覚の 範疇にとどまらず, 大脳皮質全体に普遍的に適 用されることが多い. 本稿では, 主に, 人に近 い視覚をもつサルのV1で明らかにされている 機能と構造の関連を理解する枠組を概説すると 共に, V1が視覚情報処理系の中でどのように位 置付けられるかに触れる，本稿の主要な部分に ついては最近の総説 ${ }^{4)} に$ 詳述した。

\section{II. 一次視覚野の機能構築}

\section{視覚情報の流れ}

サルの大脳皮質一次視覚野は後頭葉皮質に属 し（図 1 下），視床の外側膝状体背側核 (dorsal lateral Geniculate nucleus: LGN) 加ら主 要な入力を受けている. 図 1 は Livingstone と Hubel $^{5)}$ の仮説の説明図を改変したものであるが, これによると視覚情報は, 網膜の $\mathrm{A}$ 細胞（パラ ソル細胞）を起源とし，LGN の大細胞層 (magnocellular layers) で中継されて V1の $4 \mathrm{C} \alpha$ 層に 入力する大細胞系 (magnocellular system) と, 網膜の B 細胞（ミジェット細胞）を起源とし， LGN の小細胞層 (parvocellular layers) で中継 され V1の $4 \mathrm{C} \beta$ 層に入力する小細胞系 (parvocellular system) の 2 つの並列なチャンネルで V1

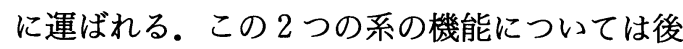
で触れるが，V1では両系の情報が必要な処理を 受けた後, より高次の処理を行う V2, V4, MT 野などに分配出力される（図 1 ）。この際, 刺 激の色や形に関する情報はV2を経て V4へ，ま た動きや立体視に関する情報はV2を経て, あ るいは直接 MT 野へというように, 情報の内容 によってそれを専門に処理する領野に情報が振 り分けられる.大脳皮質の視覚領野には階層性 があり，より高次の領野に進むほど情報は統合 されていくが, 高次の視覚野からはV1に対して フィードバックの神経結合があり ${ }^{6)}$, 効率よく情 報処理を行うようにV1の活動特性がコントロー ルされていると考えられる。またV1からは皮質 下視覚中枢である LGN や中脳の上丘 (superior colliculus)に対しても投射がある.

\section{網膜部位再現, 視野地図}

外界は 3 次元空間であり, 網膜上に投影された
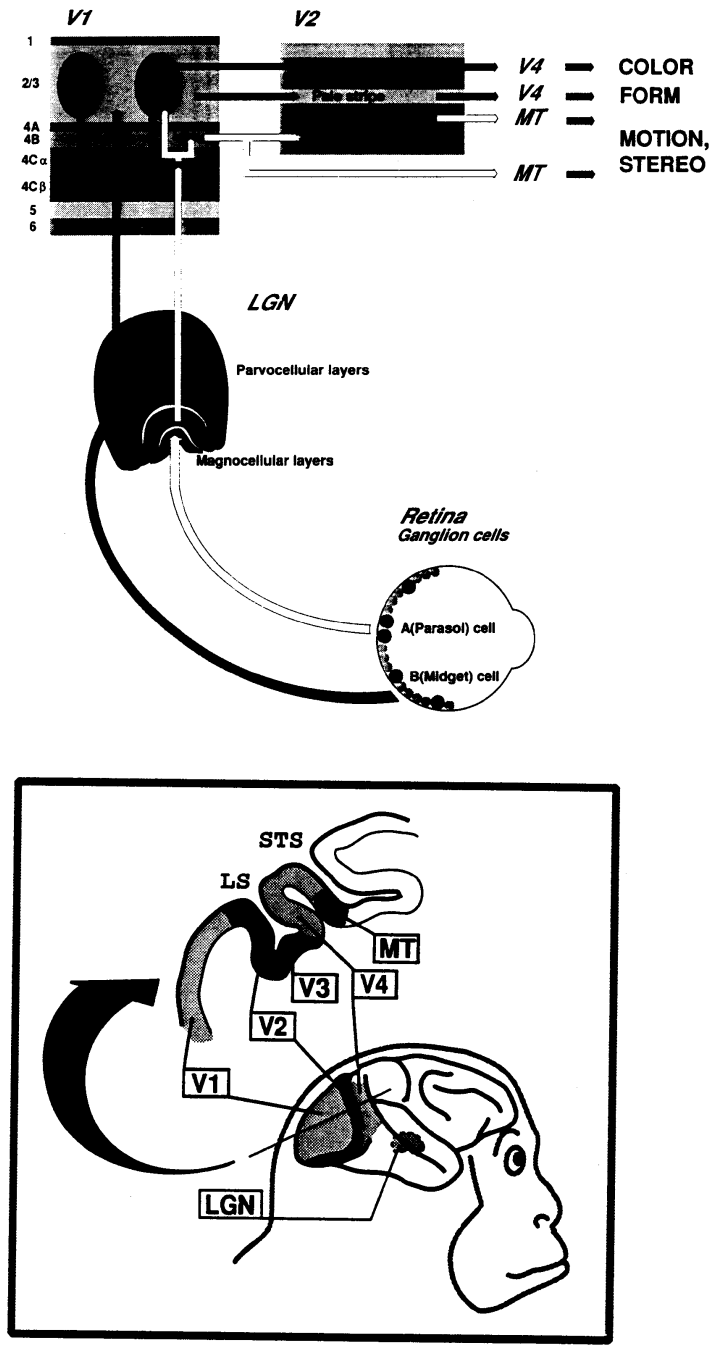

图 1 一次視觉野を経由する視觉投射路の分化と機能 白抜きの矢印は大細胞系 (Magnocellular System), 黒い矢印は小細胞系 (Parvocellular System) の情報の流れを示す.V1は 1 層から 6 層 までの模式図であるが, V2は皮質表面に対して 平行な切片標本の模式図であり, チトクローム 酸化酵素染色によるストライプパターンが示し てある. 右の枠内はサルの視覚野の位置, およ び後頭葉皮質の矢状断面図で視覚領野の分布と 脳溝の位置関係を示す. LS : 月状溝, STS：上 側頭溝, $\mathrm{V} 1 \sim \mathrm{V} 4$ : 一次 四次視覚野, $\mathrm{MT}$ : 上 側頭溝後壁視覚野. その他は本文参照. (文献 5 より改変)

情報は 2 次元である. 個々の V1ニューロンは視 野内のごく限られた範囲の情報を処理しており, 視覚刺激が呈示されることによりニューロン活動 が誘発される視野内の場所を受容野 (receptive 


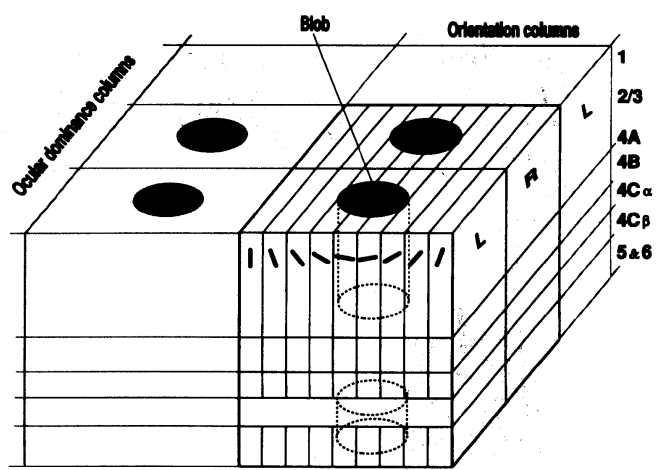

図 2 一次視觉野の機能円柱の配列模式図 (文献 12 よ り改変)

field) という. 通常, サル V1ニューロンの受容 野の中心部分の大きさは視角にして 1 度以下で ある.V1では網膜上の情報がばらばらになって 処理されるのではなく, 網膜上の 2 次元的な位 置の連続性が再現されている。これを網膜部位 再現 (retinotopic representation) という。その ためV1のどこに視野内のどの部分の情報が伝え られるかは決まっており，1941年7)にはサル V1 の視野地図 (visual field map) が作られている。 一側の V1には対側視野が再現されている。サル の V1は後頭葉表面に広く露出しているが，その 主要な部分は中心視野の情報を処理するのに使 われており, 視野の中心から視覚にして 8 度以 上偏位した視野部分（周辺視野）は，後頭葉皮 質の正中内側面の狭い部分に再現されている.

\section{層分化}

サルの V1は，他の新皮質領野と同様に，表面 から白質境界部分まで 6 つの層に分けることが できる ${ }^{8), 9)}$ (図 1，2）。層は横方向の機能的, 構 造的単位である.V1は新皮質でも最も 4 層が発 達しており，4 つの亜層からなる。 $4 \mathrm{C} \alpha, 4 \mathrm{C} \beta$ 層 は LGN からの入力を受ける層であり，2/3層は 高次視覚野に出力する層である。 5 層は $2 / 3$ 層か ら入力を受け, 上丘, 視床枕などに出力すると ともに 6 層に入力を与える。 6 層ニューロンは LGN に出力してフィードバック回路を作る. 各 層を構成するニューロンは種類が異なり, 受容 野の構造や光反応特性も異なる. 即ちV1内部で も層による階層性が見られ，同一層内で視覚情 報について同レベルの処理を行い，更に異なる
層の間を情報が受渡しされることにより処理が 進む. 但し，同一層が全く均一な細胞集団とい うわけではなく，たとえば，後述する $2 / 3$ 層は， 刺激の色に選択的な反応を示すニューロンが集 まっている場所 (ブロッブ, 図 1，2）が, 色 に選択性をもたず，刺激の傾きに強い選択性を もつニューロン群の間に埋め込まれている。こ れは $2 / 3$ 層が他の領野への主な出力層であると 共に，上述の大細胞系と小細胞系の情報が V1内 での相互作用を経て再編されながらも，情報の 種類についての並列性を保持していることに関 連している。

\section{刺激特異性と機能円柱}

V1ニューロンは, 受容野内の光刺激に常に同じ 様に反応するわけではなく, 刺激の特定の傾き, 長さ, 運動方向, 色, 空間周波数などに選択性を

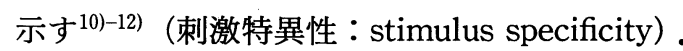
例えば，縦の線分刺激には反応するが，横向き の線分には反応しないというような傾き（方位） 選択性 (orientation selectivity)や，赤いスポッ トの点滅には反応するが，青いスポットには反応 しないというような色選択性 (color selectivity) などである。これは視覚刺激の特定の性質を抽 出し, 刺激の図形的特徵を検出するためのメカ ニズムと考えられる。

V1のほとんど全てのニューロンが視覚刺激の 何らかの特徵についての選択的反応性を持って いる. 各々のニューロンの刺激特異性はニューロ ンによって全くランダムに決まっているわけで はなく, 視野内の共通の場所に受容野を持ち, 共 通の刺激特異性をもつニューロンが集まって，皮 質の表層から深層まで灰白質を貫くように規則 的に配列されている。このような機能的, 構造的 な情報処理のモジュールは機能円柱 (functional column) と呼ばれる. 図 2 に視野の共通の場所 に受容野をもつニューロン群で形成される眼球優 位性コラム (ocular dominance column), 色選 択性コラム (ブロッブ) (color-specific column, blob), 傾き（方位）選択性コラム (orientation column) がどのような位置関係で配列されてい るかを模式的に示した。

視床 LGN から V1への入力は単眼性であり, 主に $4 \mathrm{C}$ 層に入るが, 両方の眼に由来する入力線 
維が 4C 層の同じ場所に重畳して終止するので はなく, 両者は約 $350 \mu \mathrm{m}$ の幅で規則的に互い違 いに配列される，V1内の情報は，機能円柱内を 主に縦方向に流れるため，4C 層以外のニューロ ンがどちらの眼からの入力により強く反応する か（眼球優位性）は，その直上あるいは直下の $4 \mathrm{C}$ 層ニューロンがどちらの眼に由来する入力を 受けているかによって決まる。そのため，同一 眼により強く反応するニューロン群が 2 層から 6 層までを貫通する柱状構造を形成するように 分布することになる。このような眼球優位性を 等しくするニューロン群の柱状分布が眼球優位 性コラムである ${ }^{13)-15)}$. 各々の眼球優位性コラム は幅が約 $350 \mu \mathrm{m}$ であるが長軸方向の長さは不特 定であり, $10 \mathrm{~mm}$ 以上の長さを持つものもある。 眼球優位性コラムの中央部には，ミトコンド リア内のチトクローム酸化酵素を酵素組織化学 的に染色した場合に斑点状に濃染されるブロッ ブと呼ばれる構造がある ${ }^{16)}$.このブロッブ内の ニューロンは刺激の傾き選択性を示さず，特定 の色刺激に選択的に反応することが知られてい $3^{15)}$.これに対してブロッブの外側のニューロン は明瞭な傾き選択性を示し，ブロッブ内のニュー ロンよりも空間周波数の高い刺激によく反応す る.また色に選択性のない反応をするニューロ ンが多い. したがってブロッブは色選択性ニュー ロンの機能円柱であるという考え方がこれまで のところ優勢である．このブロッブは，染まり 方に濃淡の差があるものの $4 \mathrm{~B}$ 層以外の全ての 層で見られ，やはり皮質の表層から深層まで灰 白質を貫く構造である。

眼球優位性コラムの長軸方向に沿って記録さ れるニューロンの光刺激の傾きに対する選択性 を調べると，その最適の傾き（最適方位）は連 続的に変化し，約 $50 \mu \mathrm{m}$ で $10^{\circ} す ゙ れ る{ }^{17)}$.すな わち，図 2 に示したように，共通の方位に関す る情報を処理するニューロン群が柱状に分布し て機能単位（方位選択性コラム）になっており， 長軸方向約 $1 \mathrm{~mm}$ の皮質で全方位 $180^{\circ}$ がカバー される.この長さ約 $1 \mathrm{~mm}$, 幅約 $700 \mu \mathrm{m}$ の左右 一対の眼球優位性コラムの中に視野内のある部 位に与えられた刺激の方位および眼球優位性に 関する情報がすべて含まれるとして，Hubel と
Wiesel はこれを超円柱 (hypercolumn) と名付 けた。但し，このV1における機能円柱の配列 様式の実体については最近注目を集めている光 学的記録法 (in vivo optical recording)によっ て，これまでの電気生理学的デー夕の多くが再 確認されているほか，新たな知見も見出されて いる ${ }^{18)-21)}$ ・たとえば Blasdelel' よると, 図 2 の模 式図に示したように，ブロッブは各眼球優位性 コラムの中央部分に位置するが，同一の眼球優 位性コラム内のブロッブを結ぶ部分（図 2 で左 右方向にブロッブで挟まれた部分）はニューロ ンの最適方位の変化が激しく, 図 2 のような眼 球優位性コラムの長軸方向に沿っての方位選択 性の連続的変化は認められないという。

\section{V 1 の役割}

\section{視覚情報を高次視覚野に分配出力}

大脳皮質視覚野において，視覚刺激に関する殆 ぞ全ての情報が入力されるのは, 視覚情報の大脳 皮質への入口となっているV1のみである.V1か らは刺激の様々の特徵に関する情報が，それを専 門に処理する複数の視覚領野に分配されて出力さ れる. 図 1 に示したように, 網膜から V1の 4C 層 に入力されるまでは, 大細胞系 (magnocellular system) と小細胞系 (parvocellular system) の 2 つの並列な経路で情報が運ばれ，前者は刺激 の運動や立体視に関する情報を運び, 後者は主 に色や詳細な形を分析するのに必要な情報を運 んでいる。これが 2 次視覚野 (V2)に出力される ときには 3 つの経路に分かれ, 色, 形態, 運動お よび立体視に関する情報が異なるチャンネルで 扱われるようになる ${ }^{5)}$. 色情報はもともと小細胞 系で運ばれるが，それが V1の 2/3層のブロッブ で大細胞系の情報と統合された後, V2のチトク ローム染色で可視化される細いストライプ領域 (thin stripe) に出力される.ブロッブにおける 小細胞系と大細胞系の合流の意義は明らかでな い.小細胞系の形に関する情報はブロッブ外領 域に送られて，V2のチトクローム染色で染まら ない領域 (pale stripe)へと出力される. 大細胞 系の運動および立体視に関する情報は主に，4B 層より V2のチトクローム染色の太いストライプ 領域 (thick stripe) およびMT 野に出力される. 
従って, V1に入力された大細胞系と小細胞系の 情報はV1で層間の流れの中で，あるいは機能 円柱内，機能円柱間で必要な処理を受ける間に， 色と形と動きおよび奥行きのチャンネルに再編 成されて V2, MT 野に出力されることになる.

\section{両眼からの情報の統合}

網膜神経節細胞も LGN の細胞も単眼反応性で あり, 両眼どちらの眼の刺激にも反応するニュー ロンが初めて見られるのがV1である，両方の眼 の視野にはズレ (視差) があり, それが奥行き知 覚の重要な手がかりとなっているが，V1にいた るまでは各眼の視野に関する情報が別々に運ば れていることによって個々のニューロンが視差 の情報を持つ必要がないが, V1では両眼の情報 が同じニューロンに収束するので，その際，視 差に関する情報もV1ニューロンに与えられてい るはずである. 実際, ネコの一次視覚野で, 複 雑型細胞と呼ばれるニューロンに両眼視差に選 択的に反応するグループが存在していることが 報告されている ${ }^{22)}$. 即ち, 視野の奥行きに関す る情報はV1に来て初めて単一ニューロンレベル で扱われるようになる。

\section{視野の統合}

V1ニューロンの受容野は, その中心部分が視 角にして 1 度以下のものが大半である.したがっ て個々のニューロンは広い視野の一点の情報を 扱うに過ぎない. しかし通常多くのニューロンの 受容野にまたがって存在している視覚刺激につ いての情報を処理するためにはそれらのニュー ロン活動を統合するメカニズムが必要である。 V1の機能円柱が縦方向の情報伝達系であること は既に述べたが，一つの機能円柱内では受容野 の位置は変わらない. 視野地図はV1表面に対 して 2 次元的に表現されているので, 視野内の 異なる場所の情報を統合するメカニズムは, V1 表面に対して平行な方向の連絡によると考えら れる、すなわち，機能円柱が縦方向の神経結合 であるのに対し，これは横方向の連絡である. V1の 2/3層の錐体細胞は, 情報を出力するため の神経軸索を白質経由で他の視覚野に伸ばすだ けでなく，その分枝を皮質表面に平行に伸ばし ており，その長さは $6 \mathrm{~mm}$ 以上に及ぶ23).この 水平軸索側枝は多数の受容野の位置を異にする
ニューロンと結合しており，視野統合のための 形態学的基礎と考えられる。これによって一個 の V1ニューロンには受容野外のかなり広い範囲 の情報が収束しており，そのニューロンの反応 特性に様々な影響を与えている。たとえば，あ る特定の傾きを持った線分に選択的に反応する 方位選択性ニューロンは, その受容野の周囲に 呈示された刺激の傾きによって活動が抑制され たり，促進されたりする ${ }^{24)}$ 。このような性質が あるために, いわゆるティルトイリュージョン (tilt illusion: 錯視図形の一種で，ある線分が， その周囲の線分の傾きの影響を受けて正しい傾 きとは異なった傾きにみえるもの）が生じると 考えられる。.また網膜上に人工的に限局した損 傷を作ったり，視野に一様なパターン刺激を呈 示し,ごく一部だけを欠損させると，それによっ て入力を遮断されたニューロンが受容野の周囲 の刺激にも反応するようになる25),26)。これは埋 めこみ現象 (filling in: 錯覚の一種で, 一様な パターン内に小さな欠損部位が生じても, 周囲 のパターンがそれを埋めてしまい，欠損が知覚 されない現象）の基礎となるメカニズムと考え られる.このようにV1のニューロンは，その受 容野内の刺激にのみ依存して活動するわけでは なく, そのニューロンの受容野の周囲に受容野 をもつニューロン群の活動による影響を受けて いる。

視覚生理学で広く用いられている微小電極法 では, 脳内の一点あるいはせいぜい数点までの ニューロン活動をとらえるのみであり, 多くの ニューロンの受容野にまたがって存在している視 覚刺激の情報がどのように統合されて脳内に視 野全体が表現されるのかという問題を扱うこと は難しい. しかし最近, Gray と Singer ら 27 -30) は，ネコのV1で異なる場所に受容野を持つ複 数のニューロンの発火に, 特定の刺激によって 誘発される律動的な振動現象 (oscillation) が見 られることを報告し, 視野内の広い範囲の情報 を統合的に処理することに関連した現象として 注目を集めている．また前述の光学的記録法は， 広い範囲のニューロン活動を同時に 2 次元的に 計測し，可視化する方法であるが，この方法は 既に，微小電極法に匹敵する時間分解能と空間 
分解能に達しており, V1の広い領域に分布して いる機能円柱が全体としてどのように統合され 情報処理を行っているか, また他の領野といか なる相互関係をもって活動しているかなどをシ ステム的見地から調べることを可能にするもの として, 今後この方法を利用した研究の発展が 期待される。

\section{文献}

1) Hubel $\mathrm{DH}$, Wiesel $\mathrm{TN}$ : Receptive fields of single neurones in the cat's striate cortex. J Physiol (Lond) 148: 574-591, 1959.

2) Hubel $\mathrm{DH}$, Wiesel $\mathrm{TN}$ : Receptive fields, binocular interaction and functional architecture in the cat's visual cortex. J Physiol (Lond) 160 : 106-154, 1962.

3) Hubel DH, Wiesel TN : Receptive fields and functional architecture of monkey striate cortex. J Physiol (Lond) 195: 215-243, 1968.

4) 佐藤宏道, 津本忠治 :一次視覚野の機能的構造. 神経研究の進歩 35：353-363, 1991.

5) Livingstone MS, Hubel DH : Segregation of form, color, movement, and depth: anatomy, physiology, and perception. Science 240: 740-749, 1988.

6) Felleman DJ, Van Essen DC : Distributed hierarchical processing in the primate cerebral cortex. Cerebral Cortex 1: 1-47, 1991.

7) Talbot SA, Marshall WH:Physiological studies on neuronal mechanisms of visual localization and discrimination. Amer J Opthal 24: 1255-1264, 1941.

8) Van Essen DC : Functional organization of primate visual cortex. pp 259-329 (Peters A, Jones EG: Cerebral Cortex. 3. Visual Cortex, 9) Plenum, New York and London, 1985).

Lund JS : Anatomical organization of macaque monkey striate visual cortex. Ann Rev Neurosci 11: 253-288, 1988.

10) Dow BM, Gouras P: Color and spatial specificity of single units in rhesus monkey foveal striate cortex. J Neurophysiol 36: 79-100, 1973.

11) Gouras P : Opponent-colour cells in different layers of foveal striate cortex. $\mathrm{J}$ Physiol (Lond) 238: 583-602, 1974.

12) Livingstone MS, Hubel DH : Anatomy and physiology of a color system in the primate visual cortex. J Neurosci 4: 309-356, 1984.

13) Wiesel TN. Hubel DH et al : Autoradio- graphic demonstration of ocular-dominance columns in the monkey striate cortex by means of transneuronal transport. Brain Res 79: 273-279, 1974.

14) LeVay $\mathrm{S}$, Hubel $\mathrm{DH}$ et al: The pattern of ocular dominance columns in macaque visual cortex revealed by a reduced silver stain. J Comp Neurol 159: 559-576, 1975.

15) Tootell RBH, Hamilton SL et al: Functional anatomy of macaque striate cortex. I. Ocular dominance, binocular interactions, and baseline conditions. J Neurosci 8: 1500-1530, 1988.

16) Horton JC, Hubel DH : Regular patchy distribution of cytochrome oxidase staining in primary visual cortex of macaque monkey. Nature 292: 762-764, 1981.

17) Hubel DH, Wiesel TN : Functional architecture of macaque monkey visual cortex. Ferrier lecture. Proc R Soc Lond (Biol) 198: 1-59, 1977.

18) Grinvald A, Frostig RD et al:Optical imaging of neuronal activity. Physiol Rev 68: 12851366, 1988.

19) Blasdel GC: Visualization of neuronal activity in monkey striate cortex. Ann Rev Physiol 51: 561-581, 1989.

20) Blasdel GC: Differential imaging of ocular dominance and orientation selectivity in monkey striate cortex. J Neurosci 12: 31153138, 1992.

21) Blasdel GC: Orientation selectivity, preference, and continuity in monkey striate cortex. J Neurosci 12: 3139-3161, 1992.

22) Ohzawa I, DeAngelis GC et al : Stereoscopic depth discrimination in the visual cortex: Neurons ideally suited as disparity detectors. Science 249: 1037-1041, 1990.

23) Gilbert CD, Wiesel TN : Morphology and intracortical projections of functionally identified neurones in cat visual cortex. Nature 280: 120-125, 1979.

24) Gilbert CD, Wiesel TN:The influence of contextual stimuli on the orientation selectivity of cells in primary visual cortex of the cat. Vision Res. 30 : 1689-1701, 1990.

25) Gilbert CD : Horizontal integration and cortical dynamics. Neuron 9: 1-13, 1992.

26) Gilbert CD, Wiesel TN : Receptive field dynamics in adult primary visual cortex. $\mathrm{Na}$ ture 356: 150-152, 1992.

27) Gray CM, König $P$ et al : Oscillatory responses in cat visual cortex exhibit inter- 
columner synchronization which reflects global stimulus properties. Nature 338: 334337, 1989.

28) Gray CM, Singer W : Stimulus-specific neuronal oscillations in orientation columns of cat visual cortex. Proc Natl Acad Sci USA 86: 1698-1702, 1989.

29) Engel AK, König P et al:Stimulus-dependent neuronal oscillations in cat visual cortex: intercolumner interaction as determined by cross-correlation analysis. Eur J Neurosci 2 : 588-606, 1990.

30) Engel AK, König $\mathrm{P}$ et al:Temporal coding in the visual cortex: new vistas on integration in the nervous system. Trends Neurosci 15: 218-226, 1992. 